\title{
Cervical Cordotomy in Terminal Cancer: Pain Relieving in Oncological Treatment
}

\section{Cordotomia cervical em câncer terminal: Alívio da dor em tratamento oncológico}

\author{
Maria Clara Cardoso Seba1수 Henrique Nicola Santo Antonio Bernardo ${ }^{1}$ () \\ Natally Marques Santiago Sarturi ${ }^{20}$ Thania Gonzalez Rossi ${ }^{2 \odot}$ Newton Maciel de Oliveira ${ }^{3 \odot}$ \\ Paulo Henrique Pires de Aguiar ${ }^{1,2,4}$
}

${ }^{1}$ Faculdade de Medicina do ABC, Santo André, SP, Brazil

2 Divison of Neurosurgery, Hospital Santa Paula, São Paulo, SP, Brazil

${ }^{3}$ Department of Histology, Pontifícia Universidade Católica de

São Paulo, Sorocaba, SP, Brazil

${ }^{4}$ Pontifícia Universidade Católica de São Paulo, Sorocaba, Brazil

\author{
Address for correspondence Maria Clara Cardoso Seba, BA, Rua José \\ Abdo Marão, 3418, Votuporanga, São Paulo, 15501-031, Brazil \\ (e-mail: mariaclaracseba@hotmail.com).
}

Arq Bras Neurocir 2021;40(1):71-77.

\begin{abstract}
Keywords

- cordotomy

- intractable pain

- neoplasms

- spinothalamic tracts

\section{Resumo}

Palavras-chave

- cordotomia

- dor intratável

- neoplasias

- tratos espinotalâmicos

Cordotomy consists in the discontinuation of the lateral spinothalamic tract (LST) in the anterolateral quadrant of the spinal cord, which aims to reduce the transference of nociceptive information in the dorsal horn of the gray matter of the spinal cord to the somatosensory cortex. The main indication is for patients with terminal cancer that have a low life expectancy. It improves the quality of life by relieving pain. The results are promising and the pain relief rate varies between 69 and $100 \%$. Generally speaking, the complications are mostly temporary and not remarkable.

A cordotomia consiste na descontinuação do trato espinotalâmico lateral (LST, na sigla em inglês) no quadrante anterolateral da medula espinhal, que visa reduzir a transferência de informações nociceptivas no corno dorsal da substância cinzenta da medula espinhal para o córtex somatossensorial. A principal indicação é para pacientes com câncer terminal com baixa expectativa de vida. Esse procedimento melhora a qualidade de vida, aliviando a dor. Os resultados são promissores e a taxa de alívio da dor varia entre 69 e 100\%. De um modo geral, as complicações são principalmente temporárias e não são notáveis.
\end{abstract}

\section{Introduction}

Cordotomy is an interventional pain procedure used in the management of intractable cancer pain. It consists in the discontinuation of the anterolateral quadrant of the spinal cord; this interruption normally occurs in the axon of the second neuron of this pathway. It is based on physiological principles of interruption of the lateral spinothalamic tract (LST) by means of thermocoagulation, to reduce the transfer of nociceptive information coming from the gray matter of the received

April 15, 2020

accepted

August 5, 2020

published online

November 26, 2020
DOI https://doi.org/

10.1055/s-0040-1718425. ISSN 0103-5355.

\footnotetext{
(c) 2020. Sociedade Brasileira de Neurocirurgia. All rights reserved. This is an open access article published by Thieme under the terms of the Creative Commons Attribution-NonDerivative-NonCommercial-License, permitting copying and reproduction so long as the original work is given appropriate credit. Contents may not be used for commercial purposes, or adapted, remixed, transformed or built upon. (https://creativecommons.org/ licenses/by-nc-nd/4.0/)

Thieme Revinter Publicações Ltda., Rua do Matoso 170, Rio de Janeiro, RJ, CEP 20270-135, Brazil
} 
posterior horn of the spinal cord that would follow in direction to the primary sensitive cortex (postcentral gyrus). ${ }^{1-6}$

The surgery is performed with the patient awake and sedated, under the effect of local anestesia., ${ }^{3,7}$ Moreover, the structure that serves as a spatial parameter for the procedure site is the dented ligament of the spinal cord; the electrode must be introduced before this structure, usually between $\mathrm{C} 1$ and $\mathrm{C} 2 .{ }^{8}$ Over time, cordotomy has become one of the most effective and reliable pain-relieving operation; nevertheless, it is essentially an ideal condition. The percentage of pain relief until death was high. Despite that, complications were common.

\section{Methods}

The PubMed database was used for bibliographic survey using cordotomy and terminal cancer as keywords. With the articles found in PubMed, a selection was made according to pain relief and complications. Therefore, articles that did not have enough information to calculate results and complications were excluded, so the articles that contained the information mentioned above were included. From this selection, the articles were organized in - Table $\mathbf{1}$ and the results were obtained.

In addition, analyzing the literature, important historical data were selected to assemble a timeline ( - Fig. 1). - Fig. $\mathbf{2}$ is a cross-sectional histological section provided by one of the authors added to a schematic drawing of the spinal cord to indicate the place of the procedure.

\section{Historical Remarks}

To organize and illustrate the important facts of the history of cordotomy, - Fig. 1 was made.

\section{Surgical Approach}

The techniques to apply cordotomy can be divided into two major groups, which are open and percutaneous cordoto- mies. Each one has both advantages and disadvantages and the main points will be covered in this topic.

First, percutaneous cordotomy is a powerful technique for cancer pain management. ${ }^{24}$ It remains the most frequently utilized neurosurgical procedure for the relief of cancer pain, particularly for unilateral pain confined to the trunk or lower limbs. ${ }^{25}$ This type of cordotomy uses radiofrequency lesions to destroy this portion of the cord. In addition, it is done with local anesthesia usually performed at the $\mathrm{C} 1-\mathrm{C} 2$ vertebrae level and prior to producing the destructive lesion. A stimulation can be done to assure that the painful area will be covered by the cordotomy. ${ }^{26}$ The best indication is unilateral pain below the shoulder in a patient with a life expectancy of $<1$ year. The major contraindication to a percutaneous cordotomy is pre-existing respiratory dysfunction on the opposite side to the one to be rendered analgesic. ${ }^{24}$

Second, open cordotomy involves cervical or thoracic laminectomy and near complete section of the anterolateral quadrant of the spinal cord, usually under general anesthesia. ${ }^{25,26}$ This procedure is usually reserved for patients who are unable to lie on the supine position or are not cooperative enough to undergo a percutaneous procedure. ${ }^{27}$

When these two techniques are brought up for comparison, it is notable that percutaneous techniques are less invasive, but open techniques remain viable options because some surgeons lack the expertise and equipment required for percutaneous procedures. ${ }^{28}$ Although the results from open cordotomy are favorable, percutaneous cordotomy is less invasive and the results are comparable. ${ }^{26}$ Therefore, percutaneous cordotomy has largely supplanted the open surgical approach, which is commonly employed even when predicted life expectancy is limited to weeks or days. The percutaneous technique is simple, safe, and effective, and is accompanied by minimal surgical and psychological trauma. ${ }^{25}$

Finally, these two great divisions of the technique are used; however, the percutaneous technique is the most used today. As for the other topics, cordotomy will be discussed without dividing into these two subgroups discussed above.

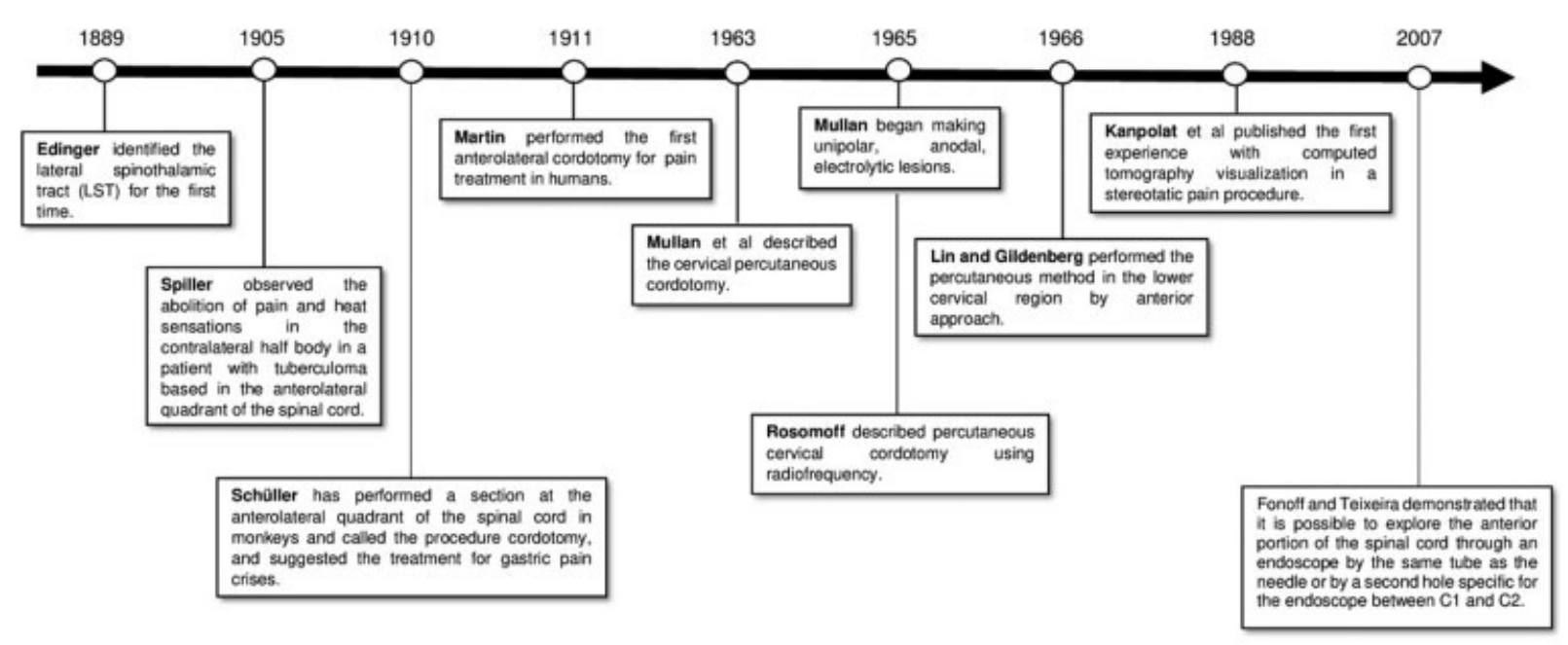

Fig. 1 Time line to illustrate the historical facts of cordotomy. ${ }^{9-23}$ 


\section{Results}

The results were obtained separately from the update table and from a previously performed article review.

First, when the table is analyzed, there is a significant improvement in pain, postoperative, in $89.1 \%$ (409/459) of the patients. In addition, in most cases, a significant reduc-

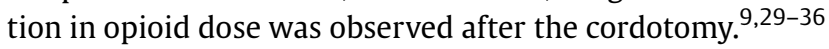

On second analysis, in the literature review, similar results are achieved: cordotomy results in immediate pain relief in 69 to $100 \%$ of the cases. ${ }^{6}$ The surgery cannot be completed in $\sim 5.4 \%$ of the cases. However, there was a reduction in the health improvement from $92.2 \%$ to $62.5 \%$ during the followup period, which was $\sim 5$ weeks. $^{23}$

When it comes to microendoscopy-guided percutaneous cordotomy, Fonoff exposes that the double channel approach presents better results than the single channel approach. The double channel approach provides a better vision and consequently a better security for the execution of the procedure. ${ }^{9}$

Several authors emphasize that cordotomy performed unilaterally presents better results than those performed bilaterally.

Moreover, to achieve satisfactory pain relief, it may be necessary to repeat percutaneous high cervical cordotomy, which is well tolerated by the severely distressed and poorrisk patient. Another detail that was commented is that if cordotomy is performed in children, the surgeon should not expect the same result as that of the one made in adults. ${ }^{30}$

According to Kanpolat, in 2009, patients may be evaluated in four groups postoperatively: Grade I - no pain; Grade II partial satisfactory pain relief; Grade III - partial non satisfactory pain relief; Grade IV - no change in pain. Grades I and

Table 1 Table of articles for updating the literature review from the procedure of cordotomy,24-31

\begin{tabular}{|c|c|c|c|c|c|}
\hline NAME & AUTHORS & YEAR & $\mathrm{N}$ & RESULTS & COMPLICATIONS \\
\hline $\begin{array}{l}\text { Open thoracic anterolateral } \\
\text { cordotomy for pain relief in } \\
\text { children: report of } 2 \text { cases }\end{array}$ & $\begin{array}{l}\text { Dora Steel; Matthew } \\
\text { A. Kirkman; Dominic } \\
\text { N. P. Thompson; Kris- } \\
\text { tian Aquilina }\end{array}$ & 2017 & 2 children & $\begin{array}{l}\text { In the first child, bilateral } \\
\text { open cordotomy at the T-5 } \\
\text { and T-6 levels, via T3-6 lam- } \\
\text { inoplasty, was performed. } \\
\text { Postoperatively, there was } \\
\text { immediate and significant } \\
\text { improvement in his pain. His } \\
\text { intrathecal analgesic treat- } \\
\text { ment was successfully dis- } \\
\text { continued. He remained at } \\
\text { home, where he died } \\
12 \text { weeks after the antero- } \\
\text { lateral cordotomy. } \\
\text { In the second child, a left } \\
\text { anterolateral cordotomy at } \\
\text { T-5. There was an immediate } \\
\text { reduction in his gluteal pain. } \\
\text { On review } 36 \text { months post- } \\
\text { operatively, analgesic medi- } \\
\text { cations have been } \\
\text { discontinued. }\end{array}$ & $\begin{array}{l}\text { No complications reported. } \\
\text { This procedure is an effective } \\
\text { treatment option for adults with } \\
\text { intractable pain, but it has sel- } \\
\text { dom been attempted in } \\
\text { children. }\end{array}$ \\
\hline $\begin{array}{l}\text { Microendoscopy-guided per- } \\
\text { cutaneous cordotomy for in- } \\
\text { tractable pain: case series of } \\
24 \text { patients }\end{array}$ & $\begin{array}{l}\text { Erich Talamoni Fonoff; } \\
\text { William Omar Contre- } \\
\text { ras Lopez; Ywzhe } \\
\text { Sifuentes Almeida de } \\
\text { Oliveira; Manoel } \\
\text { Jacobsen Teixeira }\end{array}$ & 2015 & 24 & $\begin{array}{l}\text { The microendoscopic dou- } \\
\text { ble-channel approach pro- } \\
\text { vided real-time visualization } \\
\text { of the target in } 91 \% \text { of the } \\
\text { cases. The other } 9 \% \text { of pro- } \\
\text { cedures were performed by } \\
\text { the single-channel tech- } \\
\text { nique. Significant analgesia } \\
\text { was achieved in }>90 \% \text { of the } \\
\text { cases. }\end{array}$ & $\begin{array}{l}\text { Two patients presented with } \\
\text { significant ataxia lasting for a } \\
\text { few weeks until total recovery. }\end{array}$ \\
\hline $\begin{array}{l}\text { The Dying Art of Percutane- } \\
\text { ous Cordotomy in Canada }\end{array}$ & $\begin{array}{l}\text { Christopher R. Honey; } \\
\text { Wendy Yeomans; } \\
\text { Albert Isaacs; C. Mi- } \\
\text { chael Honey }\end{array}$ & 2014 & 4 & $\begin{array}{l}\text { The pain relief following cor- } \\
\text { dotomy is immediate and } \\
\text { care must be taken to ensure } \\
\text { appropriate opioid } \\
\text { reduction. }\end{array}$ & $\begin{array}{l}\text { In this very small cohort of } \\
\text { patients, there has been no } \\
\text { major complications. } \\
\text { Patient 1: signs of depression. } \\
\text { Patient 3: symptoms of contin- } \\
\text { ued bleeding. } \\
\text { Patient 4: neck pain persisted. }\end{array}$ \\
\hline $\begin{array}{l}\text { Percutaneous cervical cor- } \\
\text { dotomy for the menagement } \\
\text { of pain from cancer: a pro- } \\
\text { spective review of } 45 \text { cases }\end{array}$ & $\begin{array}{l}\text { Emma Bain; Heino } \\
\text { Hugel; Manohar } \\
\text { Sharma }\end{array}$ & 2013 & 45 & $\begin{array}{l}\text { Thirty-two patients experi- } \\
\text { enced significant pain relief } \\
\text { on day } 2 \text {. At } 28 \text { days, } 21 \text { from } \\
34 \text { patients followed-up } \\
\text { reported maximal and aver- } \\
\text { age pain scores of zero. At } \\
2 \text { days postprocedure, } 43 \\
\text { patients stated it was } \\
\text { worthwhile; at } 28 \text { days this } \\
\text { number had decreased to } 39 \text {. }\end{array}$ & $\begin{array}{l}\text { Adverse events after percuta- } \\
\text { neous cervical cordotomy in- } \\
\text { clude respiratory insufficiency, } \\
\text { headache, increase in pain, mir- } \\
\text { ror pain, dysaesthesia and mo- } \\
\text { tor weakness. } \\
\text { Headache was the most com- } \\
\text { mon problem observed in } 20 \\
\text { patients. } \\
\text { Mirror pain was reported in } 13 \\
\text { patients. }\end{array}$ \\
\hline
\end{tabular}


74 Cordotomy in Terminal Cancer Seba et al.

Table 1 (Continued)

\begin{tabular}{|c|c|c|c|c|c|}
\hline NAME & AUTHORS & YEAR & $\mathrm{N}$ & RESULTS & COMPLICATIONS \\
\hline & & & & & $\begin{array}{l}\text { These complications didnit af- } \\
\text { fect the patients̀ good recovery. }\end{array}$ \\
\hline $\begin{array}{l}\text { Percutaneous cervical cor- } \\
\text { dotomy for non-cancer pain } \\
\text { in a patient with terminal } \\
\text { esophageal carcinoma }\end{array}$ & $\begin{array}{l}\text { Jacquelyn Lewin; } \\
\text { Heino Hugel; Manohar } \\
\text { L. Sharma }\end{array}$ & 2012 & 1 & $\begin{array}{l}\text { The pain relief was immedi- } \\
\text { ate and the patient died } \\
11 \text { months later with no re- } \\
\text { currence of the right-sided } \\
\text { pain. }\end{array}$ & $\begin{array}{l}\text { The patient had a transient oc- } \\
\text { cipital headache following the } \\
\text { procedure. }\end{array}$ \\
\hline $\begin{array}{l}\text { Computed tomography- } \\
\text { guided percutaneous cor- } \\
\text { dotomy for intractable pain } \\
\text { in malignancy }\end{array}$ & $\begin{array}{l}\text { Yucel Kanpolat; Hasan } \\
\text { Caglar Ugur; Murat } \\
\text { Ayten; Atilla Halil } \\
\text { Elhan }\end{array}$ & 2009 & 207 & $\begin{array}{l}\text { Immediately postoperative- } \\
\text { ly: } 92.5 \% \text { patients reported } \\
\text { pain relief. The initial success } \\
\text { rate was slightly higher in the } \\
\text { malignancy group. In the } \\
\text { cancer group, selective cor- } \\
\text { dotomy was achieved in } 83 \% \text {. } \\
\text { In } 12 \text { cases, bilateral selec- } \\
\text { tive percutaneous cordot- } \\
\text { omy was successfully } \\
\text { applied. }\end{array}$ & $\begin{array}{l}\text { The complications in the con- } \\
\text { ventional cordotomy are greater } \\
\text { than in the computed tomogra- } \\
\text { phy-guided percutaneous cor- } \\
\text { dotomy. In the computed } \\
\text { tomography-guided percutane- } \\
\text { ous cordotomy, the creation of } \\
\text { large lesions with thick electro- } \\
\text { des is a complication. } \\
\text { Complications: } 5 \text { cases ( } 2.4 \%) \\
\text { with temporary slight motor } \\
\text { paralysis; } 5 \text { cases with tempo- } \\
\text { rary ataxia. In bilateral cordot- } \\
\text { omy, there were } 3 \text { cases (1.4\%) } \\
\text { of temporary hypotension and } 2 \\
\text { cases (0.9\%) of temporary uri- } \\
\text { nary retention. The only per- } \\
\text { manent complication } \\
\text { postcordotomy in our series was } \\
\text { dysesthesia, seen in } 4 \text { cases } \\
\text { (1.9\%). } \\
\text { Most complications after this } \\
\text { procedure are attributable to } \\
\text { bilateral lesioning of the ante- } \\
\text { romedial portion of the spinal } \\
\text { cord. There were no complica- } \\
\text { tions in the cases with intracta- } \\
\text { ble benign pain. }\end{array}$ \\
\hline $\begin{array}{l}\text { The present role of percuta- } \\
\text { neous cervical cordotomy for } \\
\text { the treatment of cancer pain }\end{array}$ & $\begin{array}{l}\text { Ben J. P. Crul; Laura M. } \\
\text { Blok; Jan van Egmond; } \\
\text { Robert T. M. van } \\
\text { Dongen }\end{array}$ & 2005 & 43 & $\begin{array}{l}\text { Immediately postoperative- } \\
\text { ly: } 41 / 43(95 \%) \text { patients } \\
\text { reported a good result. Dur- } \\
\text { ing follow-up until death: } \\
34 / 40 \text { patients obtained } \\
\text { good pain control. In } 4 \\
\text { patients, percutaneous cer- } \\
\text { vical cordotomy had to be } \\
\text { repeated; } 3 \text { satisfied patients } \\
\text { and one was treated with } \\
\text { continuous intrathecal infu- } \\
\text { sion with morphine and } \\
\text { bupivacaine. In } 3 \text { patients, } \\
\text { percutaneous cervical cor- } \\
\text { dotomy was performed bi- } \\
\text { laterally with good results } \\
\text { and no complications. }\end{array}$ & $\begin{array}{l}\text { Only one patient had a perma- } \\
\text { nent partial loss of muscle } \\
\text { power in his ipsilateral lower } \\
\text { limb. Common complications: } \\
\text { mirror pain ( } 7) \text {; muscle weak- } \\
\text { ness (2); short lasting apnea (1); } \\
\text { bladder dysfunction (1). These } \\
\text { complications are mostly } \\
\text { transient. }\end{array}$ \\
\hline $\begin{array}{l}\text { Percutaneous cervical cor- } \\
\text { dotomy for the control of } \\
\text { pain in patients with pleural } \\
\text { mesothelioma }\end{array}$ & $\begin{array}{l}\text { M B Jackson; D } \\
\text { pounder; C price; A W } \\
\text { Matthews; E Neville }\end{array}$ & 1999 & 53 & $\begin{array}{l}\text { It can be inferred that most } \\
\text { of the patients in this series } \\
\text { ( } 83 \% \text { ) had a significant re- } \\
\text { duction in pain, and } 20 \text { of } 52 \\
\text { ( } 38 \% \text { ) were able to stop opi- } \\
\text { oid medication completely. }\end{array}$ & $\begin{array}{l}\text { Two patients experienced trou- } \\
\text { blesome dysesthesia following } \\
\text { cervical cordotomy and persis- } \\
\text { tent motor weakness was noted } \\
\text { in four. }\end{array}$ \\
\hline $\begin{array}{l}\text { Safety of Unilateral and Bi- } \\
\text { lateral Percutaneous Cervical } \\
\text { Cordotomy in } 80 \text { Terminally } \\
\text { ill Cancer Patients }\end{array}$ & $\begin{array}{l}\text { Michael Sanders; } \\
\text { Wouter Zuurmond }\end{array}$ & 1995 & $\begin{array}{l}\text { Percutaneous cervi- } \\
\text { cal cordotomy: } 62 \\
\text { Bilateral percutane- } \\
\text { ous cervical cordot- } \\
\text { omy: } 18 \\
\text { Total: } 80\end{array}$ & $\begin{array}{l}\text { Percutaneous cervical cor- } \\
\text { dotomy: } 54 \text { satisfied } \\
\text { patients; } 6 \text { partial and } 2 \text { no } \\
\text { pain relief. } \\
\text { Bilateral percutaneous cervi- } \\
\text { cal cordotomy: } 9 \text { satisfied } \\
\text { patients; } 6 \text { partial and } 3 \text { no } \\
\text { pain relief. }\end{array}$ & $\begin{array}{l}\text { The permanent complications in } \\
\text { percutaneous cervical cordot- } \\
\text { omy were urinary retention in } \\
6.5 \% \text {, hemiparesis in } 8.1 \% \text {, mir- } \\
\text { ror-image pain in } 6.5 \% \text { and } \\
\text { Horneŕs syndrome in } 100 \% \text {. } \\
\text { The permanents complications } \\
\text { in Bilateral percutaneous cervi- } \\
\text { cal cordotomy were urinary re- } \\
\text { tention in } 11.1 \% \text {, hemiparesis in } \\
11.1 \% \text {, mirror-image pain in } \\
5.6 \% \text { and Horneŕs syndrome in } \\
100 \% \text {. }\end{array}$ \\
\hline
\end{tabular}


II were accepted as successful outcome and grades III and IV as unsuccessful. The results were that $92 \%$ reported initial pain relief (grades I-II). ${ }^{37}$

In summary, cordotomy is an immediate analgesic effect that can promptly and significantly improve quality of life and reduce opioid use in this patient population.

- Table 1 shows these results according to each article researched. ${ }^{9,29-36}$

\section{Discussion}

\section{Functional Anatomical Basis for the Procedure}

Cordotomy is a procedure performed in the LST, which is located in the anterolateral portion of the spinal cord as seen in -Fig. 2. This tract carries information from pain and temperature stimuli. ${ }^{4-6}$

The stimulus is captured by nociceptors and thermoceptors present in the skin. This will be transmitted to the first order neuron that penetrates the spinal cord through the posterior root of a spinal nerve, which is characterized by having its body located in the sensory ganglion of that nerve. When it penetrates the spinal cord through the posterior horn, a synapse is performed with the second neuron in the gray matter of the spinal cord itself, it is crisscrossed at the height of the spinal cord through the anterior white commissure. The fibers of the second neuron go to the brainstem, where they will follow as spinal lemniscus to the thalamus. There, these axons synapse with the third neuron and this will reach the somatosensory cortex located in the postcentral gyrus of the parietal lobe.

Segmentation of fibers provides the opportunity for selective cordotomy, given that anteromedial lesions denervate the contralateral arm and upper chest region, whereas posterolateral lesions denervate the sacral and lumbar area. ${ }^{4}$

According to - Fig. 2, cordotomy, which consists of the interruption of the LST at the medullary level, is performed by introducing a needle into the subarachnoid space between $\mathrm{C} 1$ and $\mathrm{C} 2$, anteriorly to the dentate ligament.

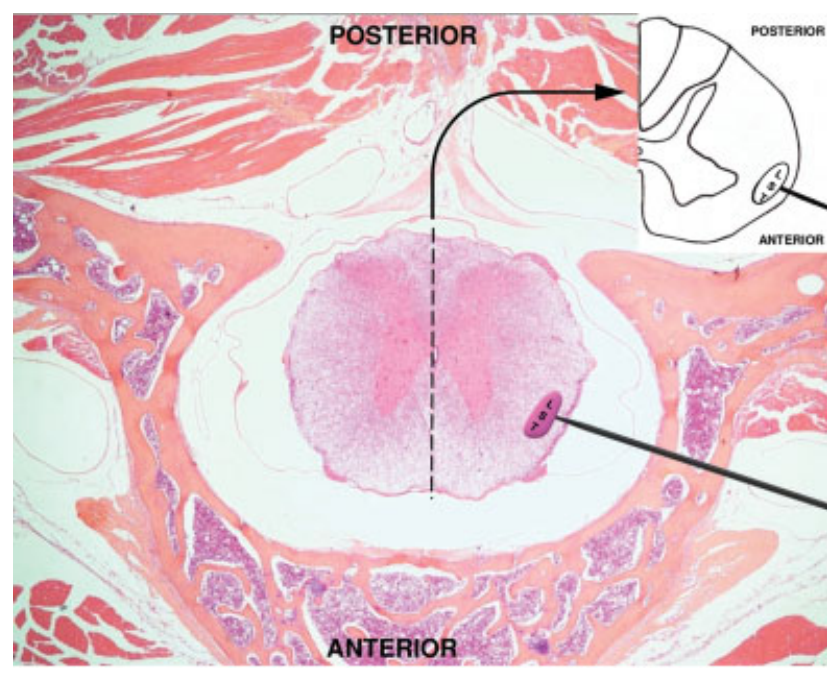

Fig. 2 Cross-sectional histological section and schematic drawing of the spinal cord aiming to represent the local of cordotomy.

\section{Indications and Contraindications}

Cordotomy can be performed safely and effectively with careful patient selection, preparation and scrupulous attention to detail. The procedure is indicated for pain treatment originated by cancer that unilaterally attacks distal segments, that is, candidates for cordotomy are patients with lateral somatic cancer pain and compression of the plexus, roots or nerves. ${ }^{23,38}$

The best candidates for computed tomography (CT)-guided percutaneous cordotomy are those with unilateral localized pain. In bilateral cordotomy, the best candidates are patients with intractable pain localized in the lower part of the body. ${ }^{8,15,37}$

In the literature, cases report that cordotomy can be made in patients that passed a long period in morphine therapy and have short life expectancy. ${ }^{39-41}$ Other authors support that the procedure presents better results in patients with life expectancy $>6$ months and have not initiated morphine therapy. ${ }^{42}$

Patients with severe pulmonary dysfunction (partial oxygen saturation $<80 \%$ ) are not suitable candidates for cordotomy. Also, patients with neck metastasis could be a contraindication for needle puncture if the compromised area is involved. ${ }^{42-44}$

\section{Complications}

As observed in - Table 1, the most frequent complications are: Horner̀s syndrome, urinary retention, arterial hypotension, sensorial ataxy, hypotony and ipsilateral hemiparesis. Right after the surgery, headache is common. Other complications are less frequent, such as: motor and sphincter or sexual deficits ( $<10 \%$ of the cases), respiratory disfunction and sleep apnea (Ondinès Syndrome). It is observed that this last one is most common when the procedure is performed bilaterally or when analgesia is related to the brachial dermatomes. Most of the complications are temporary and not remarkable. ${ }^{9,29-36}$

Lahuerta observed that complications usually occurred when the lesion of cordotomy had an extension of $>20 \%$ of the spinal cord. ${ }^{45}$

When the procedure is performed unilaterally, occasionally contralateral pain from the original pain (mirror pain) can be manifested. When analyzed, bilateral cordotomy is not recommended for upper trunk pain because of the risk of respiratory complications. ${ }^{44}$ Furthermore, cervical cordotomy should be avoided in patients with respiratory insufficiency.

Finally, to avoid other complications, the surgeon must remember not to stop morphine therapy suddenly. The conduct is to reduce their dosages progressively and discontinue morphine use over time.

\section{Conclusions}

Cordotomy provides excellent pain relief in the contralateral hemibody. Cordotomy should be included in the patient care pathway of those suffering from severe unilateral pain that has failed to respond to medication therapy. However, cordotomy performed in children is not as suitable and safe as in adults. 
Cordotomy consists in the discontinuation of the spinothalamic tract in the anterolateral quadrant of the spinal cord.

The outcome is promising, achieving immediate pain relief in 69 to $100 \%$ of the cases, and mainly temporary or not remarkable complications.

Edinger, Spiller and Rosomoff are some of the researches committed with the development of cordotomy. Also, the work of Fonoff with microendoscopy provides the possibility of a safer procedure.

In summary, cordotomy has become the most effective and reliable pain-relieving operation. Operative intervention is indicated in the management of pain when the cause defies more direct treatment and when the severity of the pain justifies the operative procedure.

\section{Note \\ Work developed at: Faculdade de Medicina do $A B C$ (FMABC). \\ Conflict of Interests \\ The authors have no conflict of interests to declare.}

\section{References}

1 Hyndman OR. Possibility of differential section of the spinothalamic tract: a clinical and histologic study. Arch Surg 1939;38(06):1036

2 Kanpolat Y, Akyar S, Cağlar S. Diametral measurements of the upper spinal cord for stereotactic pain procedures: experimental and clinical study. Surg Neurol 1995;43(05):478-482, discussion 482-483

3 Lorenz R. Methods of Percutaneous Spino-Thalamic Tract Section. In: Krayenbühl H, Brihaye J, Loew F, Logue V, Mingrino S, Pertuiset B, et al., editors. Advances and Technical Standards in Neurosurgery [Internet]. Vienna: Springer Vienna; 1976:123-45. Available at: https://doi.org/10.1007/978-3-7091-7080-9_6

4 Taren JA, Davis R, Crosby EC. Target physiologic corroboration in stereotaxic cervical cordotomy. J Neurosurg 1969;30(05):569-584

5 Walker AE. The spinothalamic tract in man. Arch Neurol Psychiatry 1940;43(02):284-298

6 White JC, Sweet WH. Pain and the neurosurgeon; a forty-year experience, Springfield, Ill.: C.C. Thomas. 1969

7 Sindou M, Jeanmonod D, Mertens P. Ablative neurosurgical procedures for the treatment of chronic pain. Neurophysiol Clin 1990;20(05):399-423

8 Kanpolat Y, Caglar S, Akyar S, Temiz C. CT-Guided Pain Procedures for Intractable Pain in Malignancy. In: Meyerson BA, Ostertag C, editors. Advances in Stereotactic and Functional Neurosurgery 11. Vienna: Springer Vienna; 1995:88-91

9 Fonoff ET, Lopez WOC, de Oliveira YSA, Teixeira MJ. Microendoscopy-guided percutaneous cordotomy for intractable pain: case series of 24 patients. J Neurosurg 2016;124(02):389-396

10 Clarke E, O'Malley CD. Function of the spinal Cord. In: Clarke E, O'Malley CD, editors. The human brain and spinal cord. San Francisco: Norman Publishing; 1996:291-322

11 Fonoff ET, de Oliveira YSA, Lopez WOC, Alho EJL, Lara NA, Teixeira MJ. Endoscopic-guided percutaneous radiofrequency cordotomy. J Neurosurg 2010;113(03):524-527

12 Kanpolat Y, Deda H, Akyar S, Bilgiç S. CT-guided Percutaneous Cordotomy. In: Broggi G, Burzaco J, Hitchcock ER, Meyerson BA, Tóth S, editors. Advances in Stereotactic and Functional Neurosurgery 8. Vienna: Springer Vienna; 1989:67-8
13 Kanpolat Y, Akyar S, Cağlar S, Unlü A, Bilgiç S. CT-guided percutaneous selective cordotomy. Acta Neurochir (Wien) 1993;123(1-2):92-96

14 Kanpolat Y, Savas A, Çaglar S, Temiz C, Akyar S. Computerized tomography-guided percutaneous bilateral selective cordotomy. Neurosurg Focus 1997;2(01):e4

15 Kanpolat Y. Cordotomy for pain. In Handbook of stereotactic and functional neurosurgery Schulder (ed) Marcel \& Dekker. New York: Basel; 2003:459-472

16 Lin PM, Gildenberg PL, Polakoff PP. An anterior approach to percutaneous lower cervical cordotomy. J Neurosurg 1966;25 (05):553-560

17 Mullan S, Harper PV, Hekmatpanah J, Torres H, Dobbin G. Percutaneous Interruption of Spinal-Pain Tracts by Means of a Strontium 90 Needle. J Neurosurg 1963;20(11):931-939

18 Mullan S, Hekmatpanah J, Dobben G, Beckman F. Percutaneous, intramedullary cordotomy utilizing the unipolar anodal electrolytic lesion. J Neurosurg 1965;22(06):548-553

19 Rosomoff HL, Brown CJ, Sheptak P. Percutaneous radiofrequency cervical cordotomy: technique. J Neurosurg 1965;23(06):639644

20 Schüller A. Über operative Durchtrennung der Rückenmarksstrange (Chordotomie). Wien Med Woch 1910;60:2292-2295

21 Spiller WG. The location within spinal cord of the fibers of temperature and pain sensations. J Nerv Ment Dis 1905; 32:318-320

22 Spiller WG, Martin E. The treatment of persistent pain of organic origin in the lower part of body by division of the anterolateral column of spinal cord. JAMA 1912;58:1489-1490

23 Teixeira MJ. Various functional procedures for pain. In: Gildenberg PL, Tasker RR (eds). Textbook of stereotatic and functional neurosurgery, Part II, facial pain. New York: The Mac Graw Hill Companies Inc; 1389-1402

24 Rosen S. chapter 174 - Percutaneous Cordotomy. In: Waldman SD, Bloch JI, editors. Pain Management [Internet]. Philadelphia: W.B. Saunders; 2007:1501-17. Available at: http://www.sciencedirect.com/science/article/pii/B9780721603346501783

25 Patt RE. 15 - Neurosurgical Intervention for Chronic Pain Problems. In: FROST EAM, editor. Clinical Anesthesia in Neurosurgery [Internet]. Butterworth-Heinemann 1991:347-81. Available at: http://www.sciencedirect.com/science/article/pii/ B9780409901719500210

26 Silvers JE, Campbell JN, Argoff CE. Chapter 42 - Neurostimulatory and Neuroablative Procedures. In: Argoff CE, McCleane G, editors. Pain Management Secrets (Third Edition) [Internet]. Third Edition Philadelphia: Mosby; 2009:323-7. Available at: http://www.sciencedirect.com/science/article/pii/ B9780323040198000421

27 Cherny NI. Chapter 43 - The management of cancer pain. In: Melzack R, Wall PD, editors. Handbook of Pain Management [Internet]. Philadelphia: Churchill Livingstone; 2003:641-66. Available at: http://www.sciencedirect.com/science/article/pii/ B9780443072017500473

28 Sather MD, Follett KA. Chapter 19 - Neurosurgical Management of Pain. In: Benzon HT, Rathmell JP, Wu CL, Turk DC, Argoff CE, editors. Raj's Practical Management of Pain (Fourth Edition) [Internet]. Fourth Edition Philadelphia: Mosby; 2008:401-11. Available at: http://www.sciencedirect.com/science/article/pii/ B9780323041843500224

29 Jackson MB, Pounder D, Price C, Matthews AW, Neville E. Percutaneous cervical cordotomy for the control of pain in patients with pleural mesothelioma. Thorax 1999;54(03): 238-241

30 Steel D, Kirkman MA, Thompson DNP, Aquilina K. Open thoracic anterolateral cordotomy for pain relief in children: report of 2 cases. J Neurosurg Pediatr 2017;20(03):278-283

31 Bain E, Hugel H, Sharma M. Percutaneous cervical cordotomy for the management of pain from cancer: a prospective review of 45 cases. J Palliat Med 2013;16(08):901-907 
32 Lewin J, Hugel H, Sharma ML. Percutaneous cervical cordotomy for non-cancer pain in a patient with terminal esophageal carcinoma. J Pain Symptom Manage 2012;43(03):e8-e9

33 Honey CR, Yeomans W, Isaacs A, Honey CM. The dying art of percutaneous cordotomy in Canada. J Palliat Med 2014;17(05):624-628

34 Crul BJP, Blok LM, van Egmond J, van Dongen RTM. The present role of percutaneous cervical cordotomy for the treatment of cancer pain. J Headache Pain 2005;6(01):24-29

35 Kanpolat Y, Ugur HC, Ayten M, Elhan AH. Computed Tomographyguided Percutaneous Cordotomy for Intractable Pain in Malignancy. Operative Neurosurgery 2009 Mar 1;64(suppl_1):ONS187-94.

36 Sanders M, Zuurmond W. Safety of unilateral and bilateral percutaneous cervical cordotomy in 80 terminally ill cancer patients. J Clin Oncol 1995;13(06):1509-1512

37 Kanpolat Y. Neurosurgical Management of Cancer Pain. In: Sindou M, editor. Practical Handbook of Neurosurgery [Internet]. Vienna: Springer Vienna; 2009 [cited 2020 Apr 7]. p. 1388407. Available at: http://link.springer.com/10.1007/978-3-21184820-3_82

38 Tasker RR, North R. Cordotomy and Myelotomy. In: North RB, Levy RM, editors. Neurosurgical Management of Pain [Internet]. New York, NY: Springer New York; 1997:191-220. Available at: https://doi.org/10.1007/978-1-4612-1938-5_15

39 Gybels JM. Indications for use of neurosurgical techniques in pain control. In: Bond MR, Charlton JE, Wolf J editors. Proceedings of the Sixt world Congress on Pain. Amsterdam: Elsevier; 475
40 Osenbach RK, Burchiel KJ. Percutaneous cordotomy. In: Kaye A, Black P (eds). Operative Neurosurgery, chapter 128. Philadelphia: ChurchillLivingstone; 1569-1579

41 Raslan AM. Percutaneous Computed Tomography-guided Radiofrequency Ablation of Upper Spinal Cord Pain Pathways for Cancer-Related Pain. Operative Neurosurgery 2008 Mar 1;62 (suppl_1):ONS226-34.

42 Kanpolat Y. Percutaneous stereotactic pain procedures: percutaneous cordotomy, extralemniscal myelotomy, trigeminal tractotomy-nucleotomy. In: Surgical Management of pain Burchiel K and editors. Stuttgart: Thieme; 2002:745-762

43 Kanpolat Y. Percutaneous destructive pain procedures on the upper spinal cord and brain stem in cancer pain: CT-guided techniques, indications and results. In: Pickard JD, Akalan N, Di Rocco C, Dolenc VV, Antunes JL, Mooij JJA, et al., editors. Advances and Technical Standards in Neurosurgery [Internet]. Vienna: Springer Vienna; 2007:147-73. Available at: https://doi.org/ 10.1007/978-3-211-47423-5_6

44 Syed ON, Komotar RJ, Winfree C. Cordotomy. In: Connolly S, Mc Khann GM, Huang J, Choudhri TF, Komotar RJ, Mocco J (eds). Fundamentals of Operative Techniques in Neurosurgery. New York: Thieme; 2010:635-638

45 Lahuerta J, Lipton S, Wells JC. Percutaneous cervical cordotomy: results and complications in a recent series of 100 patients. Ann R Coll Surg Engl 1985;67(01):41-44 